\title{
Jannal BASIS
}

Vol. 7 No. 2 October 2020

\section{MAINTAINING THE HARMONY OF NATURE BEHIND THE EXISTENCE OF BATU BELAH MYTH IN KAMPONG TUA NONGSA}

\author{
Tomi Arianto ${ }^{1}$ \\ Universitas Putera Batam, Kepulauan Riau, Indonesia \\ Tomi.arianto@puterabatam.ac.id ${ }^{1}$ \\ Melly Siska Suryani ${ }^{2}$ \\ Universitas Putera Batam, Kepulauan Riau, Indonesia \\ melly.siska@puterabatam.ac.id ${ }^{2}$
}

\begin{abstract}
This study aimed to explore the harmonious relationship between human and nature that is still maintained by the Malay people of Kampong Tua Nongsa in Batam. Everyone who visited Batam will have perception that Batam is an industrial city with various metropolis conditions. It cannot be denied that it is true. The industrialization magnet in Batam has attracted the attention of many immigrants from various regions to try their luck to be better. The effects of rapid immigration and the many industrialization of Batam have had quite an impact on environmental conditions, especially this island which is bordering with Malaysia and Singapore. The amount of industrial pollution, deforestation, settlements, and reclamation has a bad impact on the natural situation. But behind all of that, Batam has uniqueness. The government still maintains there are 37 points of Kampong Tua Malay scattered throughout Batam. Behind the glamor of Batam's industrialization, there are still remnants of Malay culture that have a close relationship with the environment. In the research conducted, researchers analyzed three of cultural objects that are still preserved, namely the Sacred of Bunbun, the Sacred of Puak, and the Sacred of Batu Belah. In this article, researchers focused on the Myths behind the Sacred of Batu Belah, which still reflected the harmonious relationship between humans and nature. By using an ecocritic approach, the researcher answers the variable related with the relationship between man and nature behind the myth. The method used is a qualitative method with in-depth interviews and observation as data collection techniques. Using critical analysis techniques, the results of this study indicated that the ecocritic representation behind the Batu Belah myth is reflected from the existence prohibitions behind it. These prohibitions show how the Malay community is still able to maintain a harmonious relationship between humans and nature.
\end{abstract}

Keywords: Myth, Nature, Malay People, Kampong Tua, Ecocritic

\section{INTRODUCTION}

This research is inspired by the importance of bringing back the values of local wisdom of the community, especially the old Malay village of Batam. The rapid industrial development, reclamation, marine stockpiling, forest logging for settlements, and industrial waste have a significant impact on the preservation of nature, the environment and the ecosystem in it (surjaatmadja, 2005). Migration of people outside Batam on a large scale due to magnetic employment and industrialization has exacerbated 
environmental damage. On the other hand, the Malay community as the first inhabitants of this research is motivated by the importance of bringing back the values of local wisdom of the community, especially the old Malay village of Batam.

The rapid industrial development, reclamation, marine stockpiling, logging of forests for settlements, and industrial waste have had a significant impact since the 231 AD century, marginalized people in remote areas have even directly felt the impact of environmental damage (Eki, 2012). Polluted water, air pollution, logging of forests and hills on a large scale seriously damages the preservation of nature and the ecosystem in it. This is due to the low awareness of society or the law that does not side with local culture (Hadi, 2012). One of the efforts to restore public awareness of environmental and natural sustainability is by upholding local wisdom and traditions.

The existence of Kampong Tua Malay sacred in Nongsa Batam is one of the cultural sites that is very rich in the values of local wisdom contained therein, especially the relationship between humans and nature. Arianto \& Simanjuntak (2020) also provided an explanation regarding how the relationship between Malay folklore can be used as a form of local wisdom that needs to be preserved. In this study, researchers conducted a study on three objects of Malay historical heritage that are thick with cultural values in them, namely the Sacred of Bunbun, the Sacred of Puak, and the Sacred of Batu Belah. In this article, researchers focused on the Myths behind the Sacred of Batu Belah, which still reflected the harmonious relationship between humans and nature. The people of the Malay village still adhere to local traditions, religious rituals, and local culture.

This is what inspired researchers to reintroduce and explore more deeply how humans and the natural environment are connected to each other so that the two are harmonious in an Ecocritic framework. The narrative structure approach is used to explore the mythical stories behind the existence of the three sacred villages of the old village of Nongsa (Arianto \& Simanjuntak, 2019). To bridge literature with people's behavior, researchers used a literary anthropological approach. Meanwhile, the relationship between humans and nature can be assessed with an approach. This research was conducted by conducting interviews with informants in the old village of Nongsa, Batam, Riau Islands. The data collection techniques used in this study were adjusted to the data source. The data sources for this research are primary data and secondary data. Primary data were obtained by field observation techniques and in-depth interviews, both in person and online by paying attention to the Covid-19 health protocol. Observations have been made since the beginning of the submission of the Ristek Dikti grant proposal. So that the researchers drew the theme of discussion about the Ecocritic Behind the Myths of the Sacred Bumbum, Puak, and Batu Belah myths for the Nongsa Malay Community in Batam. In the in-depth interview, the questions posed have been arranged in advance to be more focused and indepth. This interview was conducted to obtain information about the object of research. In this case the interview is aimed at the selected informant because it is considered that they know the ins and outs of the object of research. In addition to primary data, this study also uses secondary data obtained from 
literature studies. This literature study includes scientific writings on the object of study and other relevant reading sources such as journals, books, newspapers, magazines as well as articles.

Humans and nature become an inseparable unity and interrelated with one another. Often with the progress of human times, these relationships forget and act arbitrarily for the convenience of humans themselves. The conditions of modernization and rapid industrialization experienced in Batam city directly address these problems (Aritenang, 2017). The amount of environmental pollution, destruction of nature, deforestation, destruction of marine life, deforestation of hills, and even excavation of the soil is the beginning of natural damage caused by attitudes that emphasize materialist benefits without caring about the environment (Hariyadi, 2006). This has become a serious problem in almost all areas in Batam. Massive human migration has exacerbated the distortion of indigenous cultures, which are still thick with the harmonious relationship between humans and nature. The interests of building settlements, expanding land for industry, tourism and entertainment centers put aside the existence of nature to be preserved. The strong influence of global elites who have materialistic power changes cultural values into materialistic advantages and even threatens the existence of social culture itself.

Ecocritic studies try to dismantle the cultural values of society which are now increasingly outdated. Ecocritic tries to overcome the presence of natural influences that shape people's culture so that there is a balanced harmonious relationship between humans and nature to protect, protect, and care for one

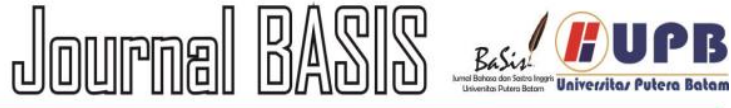

another (Hilmanto, 2010). Likewise, what happens to the culture of the community which is still eliminated but still maintains the traditions and social moral laws that stick to the balance of nature. One of them is found in the community of Kampong Tua Malay in Nongsa, Batam, Riau Islands. The Ecocritic reflection that builds the culture of the community comes from the existence of three sacred locations that are continuously guarded by the community along with the cultural behaviors that accompany them. By examining in depth about the existence of the sacred in Kampong Tua Malay, the researchers draw a research theme entitled Maintaining the harmony of nature behind the existence of batuelah myth by kampong lama malays nongsa.

\section{LITERATURE REVIEW}

\section{.1. Oral Literature}

Oral literature is knowledge and customs passed down from generation to generation orally. Oral literature is the work of art and customary law that is sustainable in a cultural process. Oral literature can exist in various forms of traditional literary works that are conveyed orally and live in the context of historical aesthetics, social structures and organizations, philosophy, ethics, and moral values. In short, oral literature is knowledge, customs, works of art, customary law, traditional literature; passed down orally; live in the context of historical aesthetics, social structures and organizations, philosophy, ethics, moral values; and sustainable in a dynamic cultural process (Taum, 2011). Taum further explained that the main element of oral literature is aesthetics. Taum added that oral literature expresses the collective awareness of local communities about life, customs and beliefs. 
One form of oral literature is myth or myth. Myth (mite) comes from the Greek mythos, meaning story, which is about the gods and heroes who are worshiped (Hutomo, 1991). Myth is considered a story that told the saint in it. According to Hutomo (1991) oral literature has several characteristics including (1) spread by word of mouth, (2) being born in a community that is still in a village, people outside the city or people who are still not familiar with letters, (3) describing the characteristics the culture of the people, (4) unknown author, (5) putisi-style, regular, and repetitive, (6) not concerned with facts and its existence, (7) consisting of sharing versions, (8) using oral language styles (everyday- day), contains a dialect, and is sometimes pronounced incompletely. Based on the characteristics above, Hutomo stated that an oral tradition can be expressed as oral literature if it has an aesthetic element in it (Sudikan, 2007).

Folk prose stories depend on Hutomo (1991) is included in the genre of pure oral literature. Folk prose stories are included in pure oral literature because in the process of conveying them only through their oracles without any other elements. According to William R Bascom in Danandjaja (1984) folk prose stories are divided into three major groups, namely: (1) Myth, (2) Legend, and (3) folktale.

As previously explained, myth is considered as a story telling a holy man in it. Bascom in Danandjaja (1984) is also in line with revealing that myth is a folk prose story that is considered to have really happened and is considered sacred by the owner of the story. Myth is confirmed by a god or demigod.

Myths in Indonesia can be divided into two types based on their place of origin, namely native to Indonesia and those from abroad such as India, Arabia, and around the Middle East. Stories that are included in myths are stories that explain the origin of a region, life, humans and other customs. Myths in Indonesia usually tell about the occurrence of the universe or cosmogony.

3. Ecocritic in Literaure

Ecocriticism in literature is an approach used to study the relationship between literature and environment based on culture in it. Glotfelty (1996) argued that literary eco-criticism focused on the discussion of literature and the environment, which means that the human environment is a stepping stone for the emergence of literary works. Garrard (2004) also argued that literary ecological criticism focuses on how we represent and describe the relationship between humans and the environment in all fields as a result of culture. Learning about nature in literary works is a learning tendency, which implies that all nature is often present in literary works in various forms.

The relationship between ecological functions and local wisdom cannot be separated from the relationship between nature and the environment. This is supported by Lestari's statement (2018) which said that ecocritical studies can use the concept of ecological environment local wisdom in literary works. Local wisdom is a reference for the community in living in various social life. Thus, ecological wisdom refers to forms of belief, knowledge, or customs that guide humans in their life related to ecological systems.

The relationship between environment, culture, and literature is also emphasized by Howarth (1996) said that Eco critic in literature can show messages of wisdom in oral literature. 
Thus, the perspective of literary ecocritic study will describe the messages and values of wisdom towards the environment in oral literature. Bergthaller (2018) added that ecocritic is one of the methods in ecological literature which aims to reveal the relationship between humans, literature and the environment. Literary ecocritical studies will show that the richness of values contained in it is the creative product of nature (in its various forms of existence) because humans are an inseparable part of it (nature).

From the description above, ecocritical study is the right paradigm to explore the relationship between literature and nature and humans as the producer of that literature. As part of oral literary culture, it cannot be separated from local wisdom because it contains values that are still held by the community from the narrative structure. Ecological wisdom is a bridge between forms of aesthetic values from literature that give birth to culture that is firmly held by society as a way of life.

\section{RESEARCH METHOD}

Moving on from Faruk (2012) statement said that data collection methods and techniques are basically a set of methods or techniques which are an extension of the human senses because the aim is to collect empirical facts related to research problems. So this type of research uses qualitative research methods because the research data is in the form of words and sentences from the informants. The research location is located in the Malay of Kampong Tua, Nongsa Batam subdistrict, Riau Islands. The research distance is $8 \mathrm{~km}$ from the research affiliation campus. The information from this research is the caretaker of the sacred Batu Belah, community advice consisting of traditional leaders, community leaders, village officials, and the younger generation of the Malay of Kampong Tua village in Nongsa who are members of the Malay village community.

\section{Data collection techniques}

The data collection techniques used in this study were adjusted to the data source. The data sources for this research are primary data and secondary data. Primary data were obtained by field observation techniques and in-depth interviews, both in person and online by paying attention to the Covid-19 health protocol. In the in-depth interview, questions that have been prepared will be asked to make it more focused and indepth. This interview was conducted to obtain information about the object of research. In this case the interview is aimed at the selected informant because it is considered that they know the ins and outs of the object of research. In collecting primary data, of course, it is also equipped with recording and recording, both through online media zoom, whatsapp, vidcam, and cellphone media as well as direct equipment such as cameras and recorders.

In addition to primary data, this study also uses secondary data obtained from literature studies. This literature study includes scientific writings on the object of study and other relevant reading sources such as journals, books, newspapers, magazines as well as articles.

\section{Data processing Technique}

The research data processing was carried out through the following techniques:

1) Research preparation group discussion forum with the research team 
2) Look again carefully at the research data sources, both primary and secondary data that have been previously collected

3) Reducing data sources, namely selecting relevant data sources with research variables, while irrelevant data sources will be ignored.

4) Describe the recorded interview results into phonemic form, then translate the Malay oral literature data into Indonesian language story texts

5) Abstract the observation results and interview transcripts so that they become data

6) Read back carefully the processed data

7) Classify data using the Greimas narrative structure approach so that the units of the story line along with the functions and story tools can be systematically arranged

8) Identifying classified data related to Ecocritic approaches.

3. Techniques to analyse the data

Data analysis for the research variables was carried out based on a qualitative descriptive method which is detailed as follows:

1) Comparing the verbal in the stories of the sacred myths of Batu Belah, either in the form of words, phrases or sentences

2) Reconfirming data through interview techniques to informants

3) Processing data and classifying it in a narrative structure scheme in order to get a systematic storyline to reach an isotopic meaning or open semantic meaning

4) Interpret the data found behind the myth story with a supportive Ecocritic approach

5) Prepare reports

\section{RESULT AND DISCUSSION}

Ecocritic representation in Kampong Tua Malay is found in the sacred of Batu Belah in puteri island. It is said that the story of this sacred stone is the crossing of a dragon that is about to cross to mainland China. However, it had not yet arrived across mainland China, it was already noon and the dragon finally became an island that was connected between the Nongsa coast and Putri Island. The crossing even forms an exotic island called the princess island. The Malay people believe that the existence of the Nongsa Island, the beach and Puteri Island across from it has quite a lot of sacred value. Therefore, there are several prohibitions that lie behind the sacred existence of slit stones.

Behind the story that is continuously believed by the ancient Malay people, it can be concluded that this story is categorized as Folk Oral Literature. There is no written evidence of this story. Every older generation of Malay people knows this story. This story was obtained from generation to generation until now researchers still have the opportunity to directly listen to myths and directly observe the location of the Putri Island.

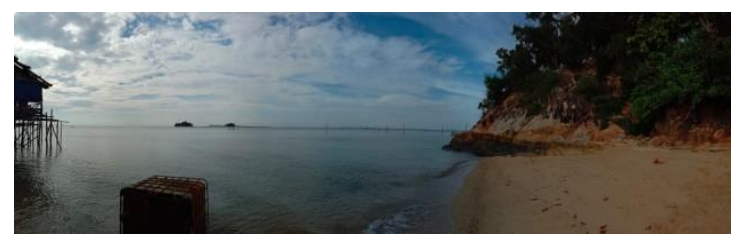

Figure 1. Panorama landscape Pesisir Nongsa dan pulau puteri yang ada diseberangnya. Tempat inilah yang dikenal sebagai the sacred of Batu Belah.

Batu Belah is actually in the form of two mainland peninsulas that are split by a bay on the coast of Nongsa. The two lands jutting out into the sea are believed to be frozen dragon legs. On the 
opposite side of the Nongsa beach there is an island that extends like a long snake. People know the island as a princess island. For the Malay people the island is known as the island of Nongsa sub-island. The island is said to be the story of a dragon's body that overslept while crossing. That is why the coastal boundary that crosses between the Nongsa coast and the mainland of Anak Nongsa Island is considered sacred or known as Batu Belah. It is not specifically known where the story originated. However, from generation to generation, the story of this myth is still believed. This is in line with various myths in the form of prohibitions that must be guarded by all visitors while on the island. The following will discuss some of the prohibitions behind the myth of the sacred of Batu Belah, which are still firmly held by the old generation of Kampong Tua Malay in Batam.

\section{Prohibition of committing adultery}

The sacred of Batu Belah is found on the island of Puteri, opposite the Kampong Tua Nongsa. Putri Island has been used as an exotic tourist attraction for the people of Batam. A beautiful stretch of sea stretches between Nongsa and Pulau Puteri. From the beach, one will be able to see an elongated island which Malay people believe is the former crossing of the dragon. To get there, people can use a boat service by paying Rp. 20,000 per person. However, there are some restrictions that visitors should avoid if they wish to cross. Among them are the following quotes:

Bagi pemuda-pemudi yang hendak menyebrang dekat pulau di larang bebuat yang tidak senonoh. Alam melihat ape yang kite lakukan [For young people who want to cross near the island, indecent acts

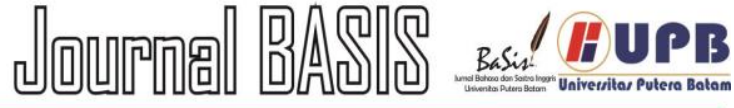

are prohibited. Nature sees what we do]

At first glance, the story seems to be just a myth that many hear as taboo when in natural attractions. However, in an ecocritical perspective, this prohibition is clearly a manifestation of the harmony between humans and nature that protect each other. Indecent acts in this case include adultery without marriage ties. Young generation today is sometimes very different from the younger generation in the past. Still dating they have dared to have a relationship like husband and wife. In terms of religious ethics it is clear that this is prohibited as well as in terms of maintaining ethics while in nature. The excerpt from an interview with a lifeguard who said Nature sees what we do means that long is a part of human life. The ethic of protecting nature is not only about keeping the environment clean. Maintaining ethics and actions is also a reflection of respecting nature as a form of beautiful creation from God.

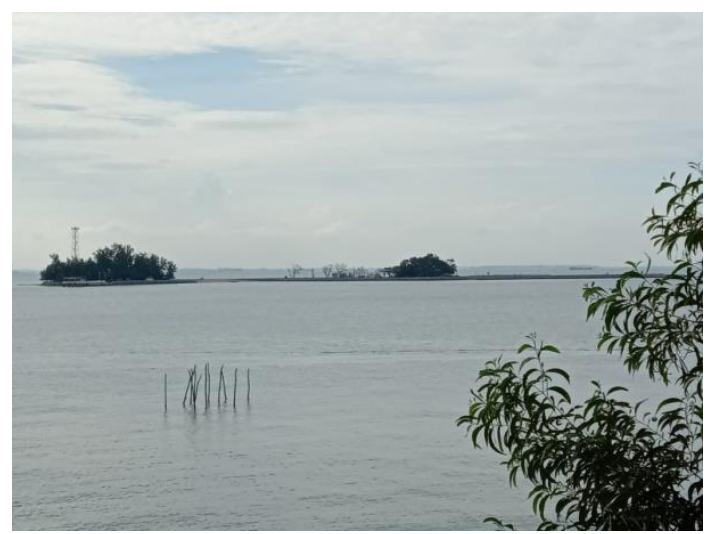

.Figure 2. Pulau Puteri which is considered as subisland of Nongsa

- Prohibition to say bad words

Apart from protecting nature, it also included keeping oral when speaking. Nature is a gift filled with beauty. This beauty will be tainted when one's awareness of guarding one's words 
is forgotten. This can be seen from the excerpt from the interview with the research informants as follows:

Laot merupekan bahagian dari keindahan, usah di kotori keindahan tesebot dengan katekate yang tak patot. betingkah lah sepatotnye saje dan sayangilah lingkungan sekitar.

[The sea is a part of beauty, do not defile that beauty with unspoken words. act properly and love the environment.]

The beauty that stretches between the island of Nongsa and the island of Princess cannot be denied. Village areas that are still beautiful and nature that is still exotic are the main attractions in these islands. No wonder many people who want to cross to Pulau Puteri just enjoy the natural beauty of the island and the clarity of the water on the side of the island. The ethics of keeping oral is a reflection of maintaining the beauty of nature while on the island. The prohibition of speaking dirty, cursing and scolding is an important point here. If someone's heart is dirty or their intentions are not good, sometimes someone is wrong to say dirty words. This often happens when one cannot appreciate the existence of nature.

- Prohibition of arbitrary waste disposal Protecting the environment from rubbish is of course a must to respect nature. Many naughty visitors are not aware of environmental concerns. The Malay community fully understands that environmental damage is also the result of human actions themselves. This is reflected in the lack of public awareness of protecting the environment. The following quotation can explain this argument.
Masyarakat Melayu yang hidup di pesiser pantai mengambek peduli dengan alam sekitarnye. Kerane tahu akan rusaknye lingkungan yang di sebabkan oleh tangan manusie itu sendiri. Secare rutin penduduk membersehkan pesiser pantai dengan jareng dan membersehkan pantai dari sampah dan kotoran. Begitupula dengan pengunjong jangan sampai membuang sampah di sembarang tempat.

[The community that lives in coastal pesiser mengambilpeduli with the natural surroundings. Because they know the damage to the environment caused by human hands themselves. residents regularly clean the beach with a net and clean the beach from rubbish and dirt. Similarly with visitors do not throw garbage anywhere.]

- Prohibition of damaging the marine environment

When nature is no longer friendly to humans, humans will reflect again on why this disaster can happen. One of them is protecting the destruction of nature due to human greed. Greedy humans sometimes exploit nature without maintaining the purity of nature itself. This includes waste from factories, settlements, reclamation, etc. If that disaster occurs, people usually reflect themselves by holding prayers asking God for forgiveness for their actions. This can be seen from the following quote:

Pernah tejadi ae laot naek ke darat, bencane datang di sebabkan manusie sudah lupe dengan sekitar. Besame sang penjage masyarakat melakukan doa hingge tujoh kali berturot-turot. Sebagai 
rase sikap menyerahkan diri kepade yang maha kuase atas kesilafan tidak mempedulikan alam sekitar.

[Once it happened ae laot up to land, disaster came because human beings had forgotten about it. Besame the guardian of the community prayed seven times in a row. As a feeling of surrender to the Almighty for mistakes do not care about the environment.]

\section{- Prohibition of cursing}

Ketike berade di laot berbicarelah seperlunye saje. Selaen menjage alam sekitar kite jugak harus menjage ucapan, perkataan dan perbuatan. Perbanyak bersyukor terhadap ciptaan Tuhan, walhal bukan sebaliknye kite memaki hamun dan merendahkan manusie laen dengan perkataan kite.

[When you are in the sea, you only need to talk. In addition to protecting the environment, the kite must also maintain speech, words and deeds. Many are thankful for God's creation, when not the other way around, we curse and humiliate other human beings with our words.]

All the quotation above are prohibitions that must be avoided by visitors who want to go to the opposite island. The prohibition is actually related to human behavior in order to protect themselves from bad deeds. The prohibition of committing adultery, saying dirty words, insulting, and polluting the marine environment are all separate behaviors. In Ecocritical studies, humans need nature to live, as well as nature needs to be preserved in order to provide benefits to humans.Vadya in Akhmadieva et al

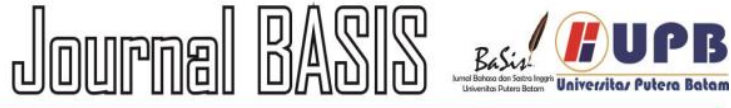

(2019) conduct further development of Ecocritical concepts about the relationship between nature and humans. Nature is a source of various possibilities to help humans fight for life. Men determine their choice of the various possibilities available. The existence of nature does not mean that which exists in the form of living things but also the stretch of islands, the expanse of the oceans and trees which are inseparable parts.

All the elements found in nature are part of beauty. This beauty is then enjoyed by humans to reassure hearts and souls. The correlation between beauty and the prohibition against bad behavior is an inseparable part. Not only actions, also attitudes and ethics are morals that need to be maintained. The relationship between nature and humans in this case can be drawn by researchers as a correlation of ethnoecological studies contained therein. Humans can appreciate the beauty of nature as well as nature can give its beauty to humans.

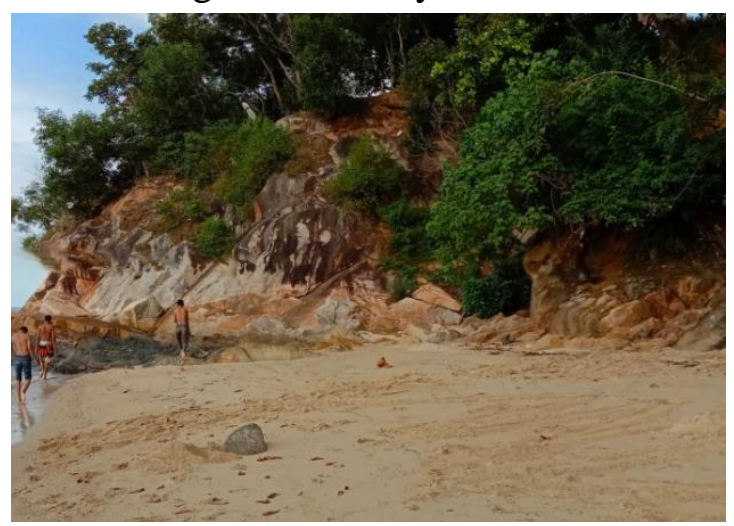

Figure 3. The sacred of Batu Belah which is considered to be the incarnation of a dragon that wants to cross the Chinese archipelago then become an island.

Ecocritical studies become the main idea in the analysis of human interaction and the natural environment. The representation of human and nature interactions is reflected in the various 
myths behind the this historical places buried. The place is known as sacred of Kampong Tua Nongsa. There are three sacred research data in this article, namely; sacred Bunbun, sacred Puak, and sacred stone. These three sacred places still exist in the midst of modernization and industrialization in Batam. Although there have been repeated attempts at relocation but it has always failed to happen. Thus, the Malay Nongsa community believes that there are various prohibitions that cannot be violated behind this sacred existence. These prohibitions become a discussion for researchers who can be analyzed from an ethnoecological perspective. All of these prohibitions cannot be separated from maintaining human behavior to respect nature, protect the environment, and behave ethically.

\section{CONCLUSION}

This representation of human and natural interactions is reflected in the various myths behind the historical places in Batam. This place is known as sacred of Batu Belah in Kampong tua Malay Nongsa. There are three sacred research data in this article, namely; sacred Bumbum, sacred Puak, and sacred of Batubelah. But in this research, researchers focused on the myth behind the story of Batu Belah. These three sacred places still exist amidst the current modernization and industrialization in Batam. Although there have been repeated attempts at relocation, it always fails. Thus, the Malay Nongsa community believes that there are various prohibitions that cannot be violated behind this sacred existence. All these prohibitions are inseparable from maintaining human behavior to respect nature, protect the environment, and conduct ethics.

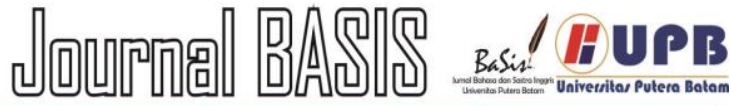

\section{REFERENCES}

Akhmadieva, R. S., Ostanin, L. M., Ostanina, S. S., Moiseyev, V. O., \& Chudnovskiy, A. D. (2019). Noxological approach to environmental protection and human life activity safety: Risks of modern dangers. 7(4), 1269-1276. https://doi.org/10.18510/hssr.2019. 74175

Arianto, T., \& Simanjuntak, D. S. (2019). Narrative structure and ecological wisdom of mak ungkai malay story in riau islands. Proceedings of EEIC, 2, 84-91. http://www.jurnal.unsyiah.ac.id/EEI C/article/view/15039

Arianto, T., \& Simanjuntak, D. S. (2020). Representation of ecocriticism in the folklore of Mak Ungkai spirit. Studies in English Language and Education, 7(2), 576-591. http://erepository.unsyiah.ac.id/SiELE/arti cle/view/16822

Aritenang, A. F. (2017). Special Economic Zone at the Crossroads: The Case of Batam. Jurnal Ilmu Sosial Dan Ilmu Politik, 21(2), 132-146. https://doi.org/http://dx.doi.org/10.2 2146/jsp.30438

Bergthaller, H. (2018). Ecological Immunity and Kim Stanley Robinson's 2312. JOE: The Journal of Ecocriticism, 8(1), 1-12.

Danandjaja, J. (1984). Folklor Indonesia: Ilmu Gosip, Dongeng, dan lain-lain. Grafiti Pers.

Eki. (2012). Ekosistem Laut Kepri Semakin Kritis. Isu Kepri, 4. 
http://www.isukepri.com/2012/12/e

kosistem-laut-kepri-semakin-kritis/

Faruk. (2012). Metode Penelitian Sastra, Sebuah Penjelajahan Awal. Pustaka Pelajar.

Garrard, G. (2004). Ecocriticsm. Routlegge.

Glotfelty. (1996). The Ecocriticism Reader: Landmarks in Literary Ecology. The University of Georgia Press.

Hadi, F. (2012, September). Kesadaran Masyarakat Terhadap Sejarah Budaya Rendah. Wartakotalive.Com.

https://wartakota.tribunnews.com/2 012/09/19/kesadaran-masyarakatterhadap-sejarah-budaya-rendah

Hariyadi, R. (2006). Pengaruh Pencemaran limbah industri terhadap kualitas air waduk; Duriangkang Batam. Jurnal Teknik Longkungan (JTL) BPPT, 7(3), 271-276.

http://ejurnal.bppt.go.id/index.php/J TL/article/\%0Aview/390/290

Hilmanto, R. (2010). Etnoekologi. Universitas Lampung.

Howarth, W. (1996). Some Principles of Ecocriticism, in Glotfelty and Fromm. University of Georgia.

Hutomo, S. S. (1991). Mutiara yang Terlupakan: Pengantar Studi Sastra Lisan. HISKI Komisariat Jawa Timur.

Lestari, U. F. (2018). Oral Literature Of Moi In Sentani Barat District, Jayapura Regency, Papua
Province: Literary Ecocriticism Study. UGM Press.

Sudikan, S. Y. (2007). Problematika Pembelajaran dan Apresiasi Sastra dan Solusinya. FBS UNESA.

surjaatmadja, J. S. (2005). Pengaruh industrialisasi terhadap kegiatan sosial ekonomi dan keseimbangan lingkungan serta kualitas lingkungan dan pembangunan berkelanjutan di pulau batam [Universitas Airlangga]. http://repository.unair.ac.id/id/eprin t/32653

Taum, Y. Y. (2011). Studi Sastra Lisan: Sejarah, Teori, Metode, dan Pendekatan Disertai Contoh Penerapannya. Lamalera. 
Vol. 7 No.2 October 2020

e-1SSN : 2406 - 9809 p-ISSN : $2527-8835$

http://ejournal.upbatam.ac.id/index.php/basis

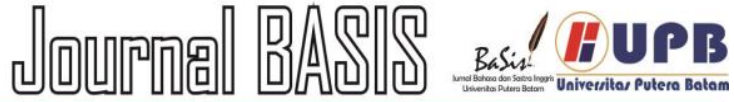

Page | 446 